Mariusz Urbanski,

Ph.D., Czestochowa University of Technology, Poland

ORCID ID, 0000-0002-5808-5209

email: murbanski@interia.eu

\title{
COMPANY GLOBAL COMPETITIVE STRATEGY AND EMPLOYEES AWARENESS
}

Abstract. In the era of industrialization, the role of company's global strategy has a significant role in surviving in a competitive environment. The global strategy has the major weapon to compete with the competitors and achieve a higher level of performance. In this direction, the awareness of global strategy among employees has key importance. However, in most companies, the level of awareness among the employees is low, which has a negative effect on the global strategy. This study aims to examine the level of awareness among employees concerning the company's global strategy. This study selected large enterprises from Poland. Data were collected from the employees of large enterprises from Poland. A cross-sectional research design was used in the present study under a quantitative research approach. In this research, first-hand data was collected from one point in time. A total of 200 questionnaires were used to collect data and distribute it to employees, of which 82 valid responses were received for data analysis. It is an important investigation that is not documented in previous studies. Particularly, large enterprises from Poland were not considered by the previous studies. This study significantly contributed to the body of knowledge. Along with the theoretical implications, the current study also has practical implications. Results of the study highlighted valuable insights for the large enterprises to enhance the company's global strategy through employee awareness. It is also evident from the results that awareness about the global strategy could promote the employee motivational level. Therefore, employees want to adopt the global strategy. Employees also highlighted that global strategy is important for brand building, innovation, and expansion to the new market. According to the employees, the major benefits of the global strategy include increasing the product quality, increasing sales, brand recognition promotion, increasing the profit, increasing the customers, gaining competitive advantage, and reducing the cost. Thus, to achieve higher performance through global strategy benefits, a company must have well planned global strategy. Therefore, the study's findings have valuable importance for the practitioners to promote large enterprises in Poland.

Keywords: global strategy, employee awareness, large enterprises, knowledge management.

Introduction. A global strategy relegates to the policies and plans developed by an organization to target growth outside the limits and borders (Wolfmayr, 2020; Stverkova et al., 2018). All the world's famous companies have global strategies aimed to increase their sales volume, no matter it is sales of goods or services. Organizations are always interested in increasing their sales outside the border of their native places. Global strategy is particularly about increasing sales across the border among different countries. In other words, global strategy refers to the plan set for the international or multinational distribution of goods or services. In this way, organizations could increase their production volume, ultimately adding value to their net profit.

Employee awareness has a crucial role in the global strategy of an organization because employees fulfill the basic needs of organizations. Moreover, employee awareness is a matter to be taken care of locally that serves the exclusive needs of the business unit. However, employees, who are aware of the global strategies of their corresponding organizations, produce maximum positive results. Employee awareness specifically relates to international security issues when an organization has global business. Employees are considered as the most important organizational resource (Karami et al., 2013; Wisse et al., 2018). Thus, the better an organization knows its employees, the better the organization can keep its employees engaged, happy and help them scope their brimming potential.

Moreover, organizations have an employee engagement strategy which is important to establish a positive emotional relationship with their employees. In this regard, the organization creates a friendly

Cite as: Urbanski, M. (2021). Company Global Competitive Strategy and Employees Awareness. Marketing and Management of Innovations, 2, 49-64. http://doi.org/10.21272/mmi.2021.2-04 
environment that helps to grow the organization's business instead of just ordering the employees to perform the required tasks. Employees are initially trained and prepared according to the business needs of an organization (Karim et al., 2012; Tahir et al., 2014). Thus, they easily able to utilize their energies to produce business for the organization. In this regard, motivation plays an essential role. Employee motivation is significant (Widokarti et al., 2019; Onyusheva, 2017). Employee motivation helps to participate both the management and employees with a collaboration knowing the organization's goals. Motivation awakens employees to increase productivity, and in this way, an organization achieves higher output levels. Hence, employee motivation is an important tool for employee engagement that ultimately helps to increase employee's awareness.

Furthermore, knowledge management by an organization has a crucial role in its employees' awareness. Knowledge management helps develop a deep connection between the organization and its employees (Al-Dmour et al., 2020; Omar et al., 2020). Employees with essential knowledge about the overall workability of their corresponding organization are orderly clear about their devoted functionalities and performances for the organization. Hence, employees knowing about the global strategy of their corresponding organization are fully capable of delivering their maximum possible potential for the organization's growth. Moreover, employees with insufficient knowledge about their corresponding organizations' global strategy are comparatively less productive for their organizations. Therefore, the objective of this study is to examine the level of awareness among employees concerning the company's global strategy.

Literature Review. Global strategy pilots' organizations to establish their business worldwide (Chen et al., 2017; Sharrock et al., 2018; Trad \& Kalpic, 2018; Kot et al. 2020). Hence, these organizations can establish a customer base, sell their services and products at a profit, and build a healthy image of their brand by applying the profit favourable circumstances related to the market. The organization that operates facilities such as distribution centers and factories in various countries worldwide is called global business. Global business is slightly different from international business. Thus, in global business, products are sold worldwide. In turn, its facilities only operate in its home country. Most organizations like to go global because they increase their profitability and sales (Chisholm et al., 2018).

Moreover, going global generates new sources of income and revenue for organizations. The global market provides the opportunity to produce a greater yield, which causes more profit for an organization with its proper global strategy. Moreover, the global business provides comparatively long-term business security and is inclined towards success for a business. Nowadays, the internet market or e-market allows global businesses to reach out to the global market with ease, peace, and without difficulties. Many businesses grow internationally to transform their assets, capital, an action that could take care of an organization's core line against unexpected, sudden and abrupt events that may have negative impacts.

While organizations ready to operate in the international market shift their business easily towards another market if they face unfavorable business-related conditions in a market. According to the results of a previous study, global markets offer substantial potential advantages such as favorable conditions to lower costs, access to new clients and consumers, dispirit challenges, and diversification of business risk. Global strategy for any organization has four main purposes: 1) Global strengthen, implementation, and development; 2) Growth in physical activities; 3) Implementation of regional and international policies; 4) Establishing engagement among all the sectors. Therefore, global strategy has key importance for business activities (Carpenter et al., 2003; Lorenzen \& Mahnke, 2002; Fitriyah, 2019; Kovacs, 2020).

The global strategy has significant benefits related to marketing services and goods. Benefits of global strategy are not only related to marketing goods and services, but besides these benefits' global strategy also enable the organization to relate with transatlantic manufacturing, partnering with multinational organizations in seek of development or products, hedging exchange rates, foreign investing, and importing services or goods to augment domestic achievements. While adopting a global strategy, the 
company gains experience in the international market with the help of collaboration with international partners, suppliers, and customers. As the customers, suppliers, and distributors are the major sources of information that bring innovation (lqbal \& Hameed, 2020). Their innovative potential could be used effectively when the company has developed channels for communication (Khuong et al., 2020; Micík and Micudova, 2018). In this regard, an effective dialogue system, including dialogue in the internal environment, could lead to expected results (Bilan et al., 2019). That is especially important when firms use the prospector strategy (Liem \& Hien, 2020), particularly exploring the competitive surrounding (Petru et al., 2018).

However, to work with the global strategy, the company must have a significant level of awareness. The employees of the company should have sufficient knowledge as well as awareness about the company. Notably, the previous studies highlighted that employees' awareness has a major role in an organization (Lukitowati \& Ramli, 2020; Rotvold, 2008). To ensure employee awareness, companies motivate them for innovative practices using a wide range of HRM tools (Bilan et al., 2020). Employees of the organization must have sufficient knowledge about the global strategy. Employee knowledge about the global strategy can push employees to promote global knowledge.

In most countries, companies move towards a global strategy. In Poland, various organizations are also pushing the strategies towards other countries and collaborating with the external partners, suppliers, and customers to promote global strategy by increasing the external collaboration. Besides, large enterprises in Poland promote the global strategy. Notably, the global strategy has several benefits, including the competitive advantages that positively affect business performance. As business performance has major importance in getting success in the market (Addison et al., 2020; Hafiz \& Sary, 2020; Hussain et al., 2020), it is essential to promote global strategy.

Methodology and research methods. Research Design: Several approaches are available in the literature to carry out a research study - for instance, quantitative research approach, qualitative research approach, and mixed-method approach. The current study is based on primary data collection. Therefore, the quantitative research approach is most suitable. While using the quantitative research approach, the current study used a cross-sectional research design. A cross-sectional research design is also suitable while collecting primary data (Chan et al., 2019). Therefore, the current study collected first-hand data on one point in time.

Sampling: The current study selected large enterprises from Poland to collect data. The employees of these companies were selected for data collection. Hence, the population of this study is large enterprises from Poland. A total of 200 questionnaires were used for data collection and distributed among the employees. Furthermore, the current study involved area cluster sampling for data collection. It stands to mention that area cluster sampling is the most suitable technique for this study because it collected data from a large spread population (Altaf et al., 2019). From total distributed questionnaires, 82 valid responses were received for data analysis.

Questionnaires Development: A questionnaire is a research instrument consisting of a series of questions to gather information from respondents. As mentioned above, the current study used a questionnaire for data collection (Zhang et al., 2017). For developing the questionnaire, measures were adapted from previous studies. In this study, the questionnaire was divided into various sections. One section was based on respondents' demographic information, and the other section was based on the key research questions to achieve the objective.

Results. This report contains answers and analysis of inquiry concerning awareness of employees about the company's global strategy. The main goal of this inquiry is to study the general awareness of employees among many companies that employ more than 250 people. We also set other extra goals. Apart from awareness, the study checks the best way to provide information about the global strategy to 
the employees and the correlation between position and awareness. More valuable data from 82 responses and more than 30 companies were analyzed.

Table 1. What is the main area of your business?

\begin{tabular}{cc}
\hline Area of business & Votes \\
\hline Construction industry & 2 \\
Services & 17 \\
Distribution & 16 \\
Transport & 19 \\
Mining industry & 2 \\
Sale & 26 \\
\hline
\end{tabular}

Sources: developed by the authors.

Table 1 shows that most people work in the business department of the producer. That could be since it is easiest to get a job in such a department because this department is looking for many employees. Besides, a significant amount of people are employed in sales and the IT industry. People in the IT industry are sought after in large numbers, but special skills are needed for this business department.

Table 2. Does your company cooperate with international partners? (select all fields that you think are true)

\begin{tabular}{cc}
\hline Answers: & Percentage answers: \\
\hline None of above & $4,88 \%$ \\
Providers & $67,07 \%$ \\
Suppliers & $78,05 \%$ \\
Clients & $80,49 \%$ \\
Other external services & $48,78 \%$ \\
\hline
\end{tabular}

Sources: developed by the authors.

Table 2 shows that employees are aware of the cooperation of their companies with international partners. The majority of the respondents could identify with which types of companies their employers cooperate with. The most common answer chosen by the respondents is various types of clients (as much as $80.49 \%$ ). Thus, these companies could grow in terms of trade and marketing. A significant part of the respondents (as much as 78.05\%) also chose suppliers. It indicates that companies value relations at the international level. Another group often chosen by the respondents is the providers $(67.07 \%)$. That is confirmed by the fact that the company values good colleagues. Many employees have also declared that their companies cooperate with other people who were not included in this survey. The results of an indepth analysis of the respondents' responses allowed concluding that international companies value cooperation. They support other members of the economy

Table 3. Is your company private or state-owned?

\begin{tabular}{cccc}
\hline All & State-owned & Private & Not sure \\
\hline 83 & 4 & 76 & 3 \\
\hline
\end{tabular}

Sources: developed by the authors.

Table 3 indicates that most people completing the inquiry know what type of company they work for. Only 3 persons are not sure, while reat 80 people know if the company they work in is private or stateowned. Notably, only 4 persons work in state-owned companies, while 76 people, works in private companies. 


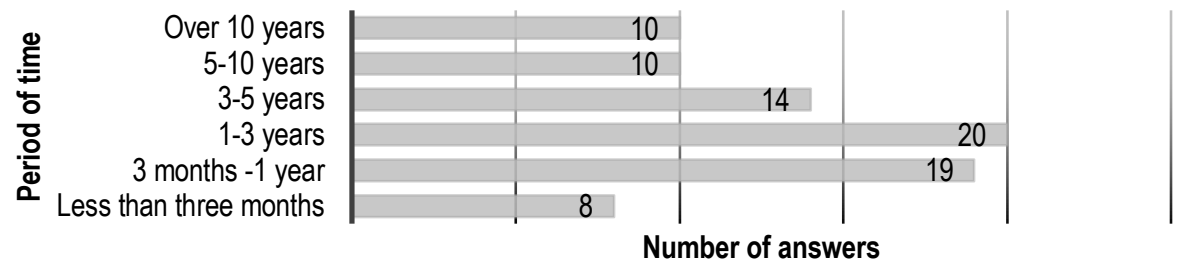

Figure 1. How long have you worked in this company?

Sources: developed by the authors.

Figure 1 shows that most respondents work in their company from 3 months up to 5 years $(53(65 \%)$ out of 82 people). The least answers came from those who worked for less than 3 months or worked for longer than 5 years. Most people responded that they have worked for 1-3 years. Nevertheless, the number of those who worked from 3 months to 1 year is almost the same. Those two answers were the most popular.

Table 4. What position do you work at?

\begin{tabular}{cc}
\hline Position & Quantity \\
\hline Employee & 24 \\
Specialist & 38 \\
Manager & 7 \\
Management & 5 \\
Middle management & 5 \\
Senior Management & 3 \\
\hline
\end{tabular}

Sources: developed by the authors.

The purpose of the survey was to examine employees about the company's global strategy. Most of the people who voted in the survey had a specialist position. The second part of the people who voted was the employees at the lowest level. The survey was structured to reach even the lowest positions in the company.

Table 5. What department do you work in?

\begin{tabular}{cc}
\hline Department type & Votes \\
\hline Engineering & 2 \\
Trainings & 2 \\
Logistics & 22 \\
Human Resources & 9 \\
Sales & 18 \\
IT & 29 \\
\hline
\end{tabular}

Sources: developed by the authors.

As Table 5 shows, most people work in the IT department. Many respondents also replied that they are employed in sales or logistics. These are very popular employee employment departments. The least people are employed in the communications department. Despite IT department is the most crowded, it is still looking for new employees. 
Table 6. Do you know if the company you work for has a global strategy?

\begin{tabular}{cc}
\hline Answers & Percentage \\
\hline A (No, it doesn't have a global strategy) & $6,10 \%$ \\
B (Yes, it has a global strategy) & $76,83 \%$ \\
C (I'm not sure if it has) & $17,07 \%$ \\
\hline
\end{tabular}

Sources: developed by the authors.

The survey aimed to examine employees' knowledge of whether they have basic information related to the scope of the companies in which they are employed. The vast majority of respondents could determine whether the company they work for is a company with or without a global strategy. Unfortunately, many employees (as much as $17.1 \%$ ) were also unable to determine whether their company has or does not have a global strategy.

Therefore, the results concluded that employees are not fully aware of companies' global development and its consequences. Moreover, it could be stated that most international companies are focused on the global development of their business. Notably, the findings showed that there are still companies that have not do not have global strategies.

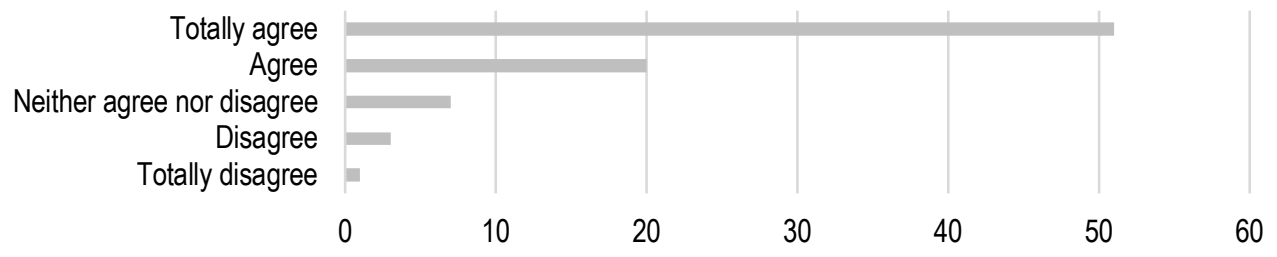

Figure 2. Do you think that having a global strategy is important?

Sources: developed by the authors.

The results of Figure 2 states that global strategy is important for the company. Thus, $86 \%$ of respondents (71 people out of 82 ) confirmed it. In turn, $62 \%$ of respondents totally agree with that statement (51 people), and another $24 \%$ agree (20 people). $9 \%$ of respondents don't have their opinion on that subject ( 7 people). Only $5 \%$ disagree with the statement, where $4 \%$ (3 people) disagree, and only $1 \%$ totally disagree ( 1 person).

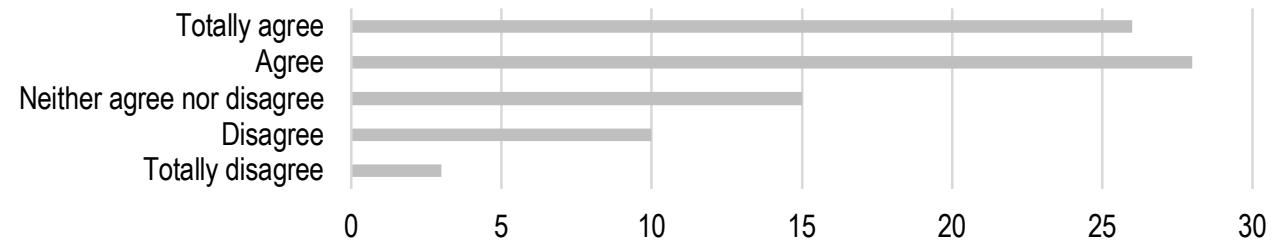

Figure 3. Are you interested in the global strategy of your company?

Sources: developed by the authors.

Notably, most surveyed people are interested in the company's global strategy, which is confirmed by $66 \%$ of respondents (54 people out of 82 ) (Figure 3). It is worth mentioning that $18 \%$ of respondents do 
not have their opinion on that subject (15 people). The remaining $12 \%$ (10 people) disagree, and $4 \%$ totally disagree (3 people).

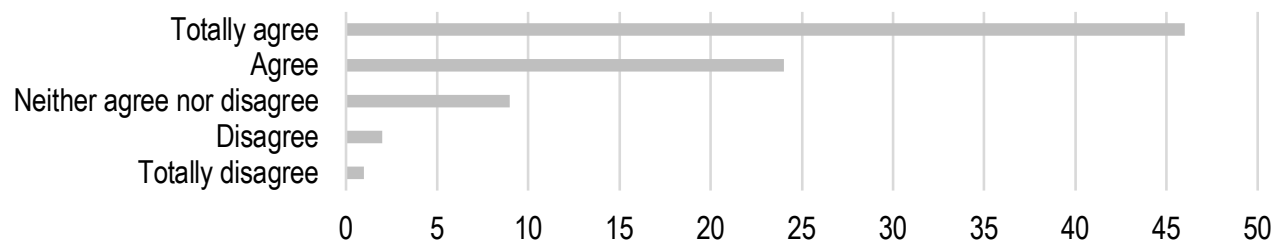

Figure 4. Do you think that having a global strategy is beneficial for the company? Sources: developed by the authors.

Results from Figure 4 show that the vast majority of respondents $(85 \%)$ agree that having the global strategy is beneficial for the company (70 people). $11 \%$ of respondents do not have their opinion on that subject ( 9 people). In turn, the remaining $4 \%$ do not agree with the statement, where $3 \%$ (2 people) disagree, and $1 \%$ totally disagree (1 person).

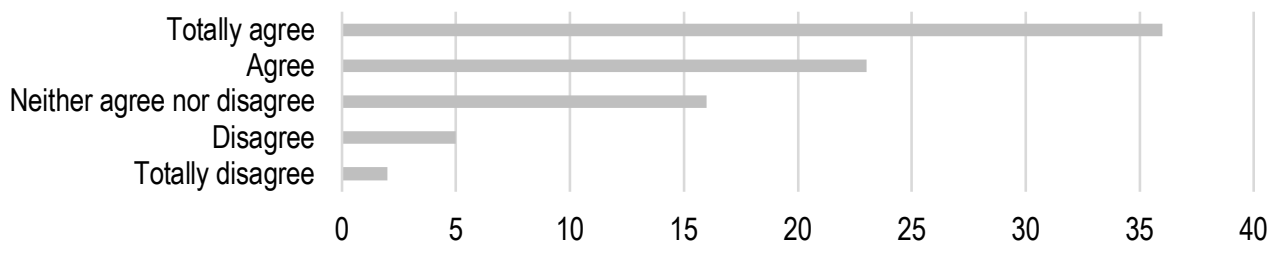

Figure 5 . Is business location important in the context of a global strategy?

Sources: developed by the authors.

The obtained results (Figure 5 ) show that $72 \%$ of respondents agree that business location is important in a global strategy (59 people). Where $44 \%$ totally agree, and another $28 \%$ agree. $20 \%$ of respondents do not have their opinion on that subject (16 people), which is puzzling. The remaining $8 \%$ do not agree with the statement, where $6 \%$ ( 5 people) disagree and $2 \%$ totally disagree ( 2 people).

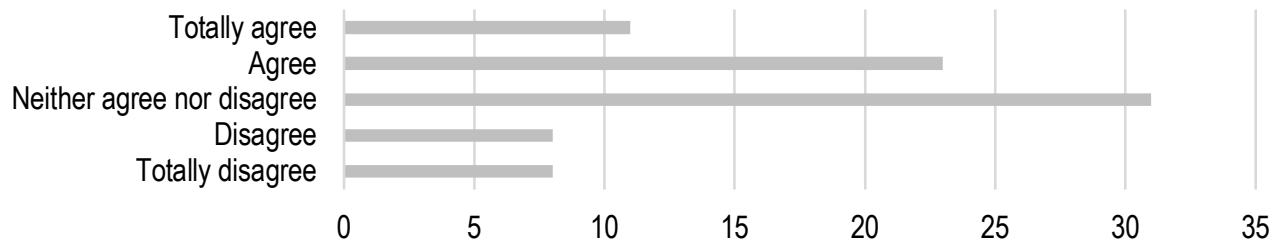

Figure 6. To what extent does awareness of the global strategy affect your motivation to work? Sources: developed by the authors.

Figure 6 shows that the global strategy affects motivation to work for $41 \%$ of respondents (34 people). Where $13 \%$ totally agree with the statement, and another $28 \%$ agree. Moreover, as many as $38 \%$ of 
respondents have no opinion on the matter (31 people). The remaining $20 \%$ do not agree with the statement, where $10 \%$ (8 people) disagree and $10 \%$ totally disagree (8 people).

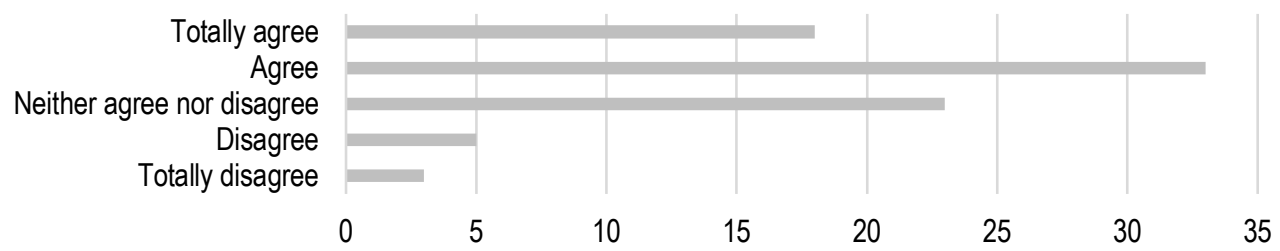

Figure 7. Is your company's global strategy properly adapted to contemporary marketing trends?

Sources: developed by the authors.

The findings (Figure 7 ) show that $62 \%$ of respondents agree with the statement that their company's global strategy is properly adapted to contemporary marketing trends (51 people). Another $28 \%$ of respondents do not have their opinion on that subject (23 people). The remaining $10 \%$ do not agree with the statement, where $6 \%$ ( 5 people) disagree and $4 \%$ totally disagree ( 3 people).

The collected data and obtained results indicate that surveyed people are aware of the existence of global strategy in their company and its impact on company activities. They also clearly agree that location is an important point in the case of global strategy. Nevertheless, they do not see global strategy as a point, which affects their work motivation. Moreover, $38 \%$ of respondents do not have their opinion on that matter. Notably, $28 \%$ of respondents have no opinion about global strategy adaptation to contemporary marketing.

Table 7. What do you think is the main goal of the global strategy in your company? (Please choose one answer)

\begin{tabular}{cc}
\hline Answers & Votes \\
\hline My company is a local player & 1 \\
Achieving performance & 13 \\
Brand building & 16 \\
Implementation of innovation & 16 \\
Expansion of new markets & 23 \\
Supplier diversification & 3 \\
Adaption & 5 \\
Risk management & 4 \\
Delivering the service up & 1 \\
Total & 82 \\
\hline
\end{tabular}

Sources: developed by the authors.

Most people (28\%) chose the answer «Expansion of new markets». That means that companies want to export their products/services. International expansion is a way to accelerate the development of a company significantly. Then, the most answered statements were «Brand building» and «Implementation of innovation». Both answers reached $20 \%$. Thus, it's precious for a company to be recognized and to focus on brand building. In turn, the implementation of innovation is also very significant for firms, 16 people voted that their main goal of global strategy is to implement innovation. The next position that had 13 votes was «Achieving performance». Indeed, it's not easy to consistently achieve performance, and for 
$16 \%$ of asked people, it's their goal. Adaptation gathered only 5 votes, which gives us $6 \%$. That means that the process of adaptation is not so important for companies.

The next chosen answer with only $5 \%$ was «Risk management». Only 4 persons out of 82 have decided on risk management. Therefore, only for 4 companies, it's important to plan their business schedules in case of crisis. Another answer that gathered 3 votes was "Supplier diversification». For $4 \%$ of all asked, it's necessary to focus on supplier diversification. Through diversification, the company reduces the likelihood of loss and reduces the likelihood of the highest profit. The last two answers had both $1 \%$ - my company is a local player and delivering the service up. Only one person voted for a local player and one for delivering the service up. It gives us feedback that one business is a local player, and maybe he's the only one in that business sector in Poland or Europe. The chart also shows that only one company focus on delivering the service up.

Table 8. Which of the following activities are in your opinion the most important in the implementation of the global strategy in the company? (Please choose one answer)

\begin{tabular}{cc}
\hline Activity & Answer \\
\hline Advanced technological infrastructure & 16 \\
Consequence & 1 \\
Innovation & 22 \\
Integration & 8 \\
Lifelong learning & 8 \\
Sustainable development & 21 \\
Total & 82 \\
\hline
\end{tabular}

Sources: developed by the authors.

Table 8 demonstrates the answers on the most important activities in implementing the global strategy in the company. 79 respondents provided answers to the question mentioned above. The data presented in Table 8 shows that most respondents indicate innovation as the most important factor in implementing the global strategy in the company, with 22 respondents out of 79 . The next crucial factor, according to the group surveyed, is sustainable development (21 answers). Notably, 16 people consider advanced technological infrastructure is vital in exercising global strategy. Integration and lifelong learning constitute $6,32 \%$ of the total 79 . Only 3 people see equal opportunity as the key factor to globalization. Finally, the consequence was mentioned only once. Concluding, the top three factors in implementing global strategy in a company are, in the order of importance: Innovation, sustainable development, and advanced technological infrastructure. The positive conclusion might be drawn from those results that corporate sustainability is fundamental for the companies that focus on the needs of the enterprise and are concerned about protecting human and natural resources. Innovation and technological advances, on the other hand, are indispensable to obtain that aim.

How much do the following activities support employees in implementing the global strategy, in your opinion?

Here the matter is not so simple. It seems that it all depends on the type of business, prospects, and the people's individual opinions completing this inquiry. More than half of responders think that is important. It would seem that the data could be really different. In theory, all these activities are interrelated. That is all about the global strategy. In practice, however, each activity is definitely a different case. For example, it was asked about: Providing information on completed stages/parts covered by the global strategy; Process supporting comparable work abroad; A common language used in company structures, Incentive remuneration system based on the achieved goals of the company's global strategy; Building trust and commitment between employers and employees. The vast majority consider that these activities are important or very important. 


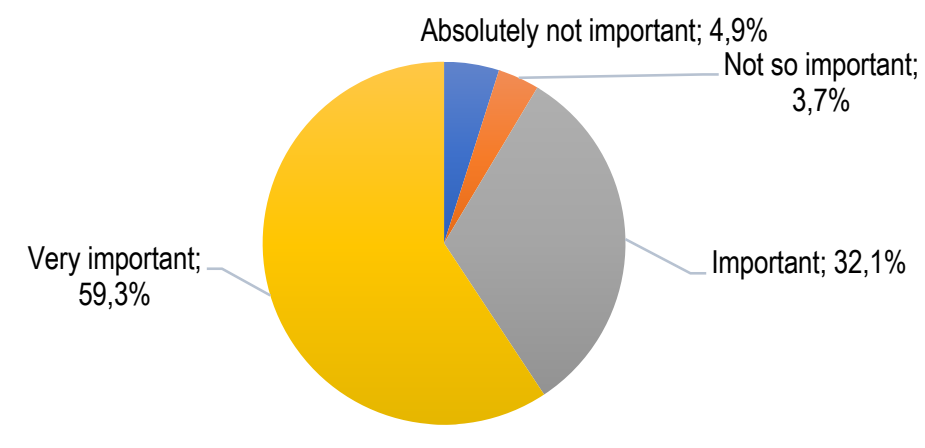

Figure 8. Providing information on completed stages/parts covered by the global strategy Sources: developed by the authors.

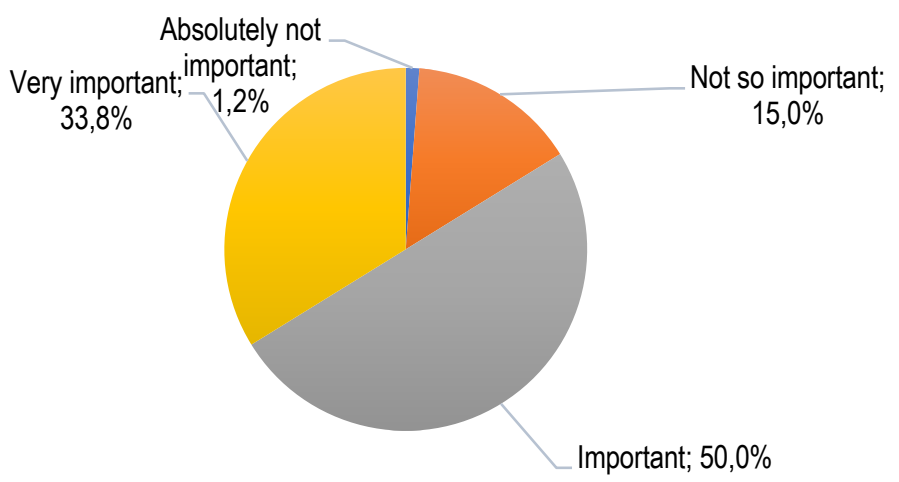

Figure 9. Process supporting comparable work abroad Sources: developed by the authors.

There are only $1.2 \%$ of people that chosen «absolutely not important».

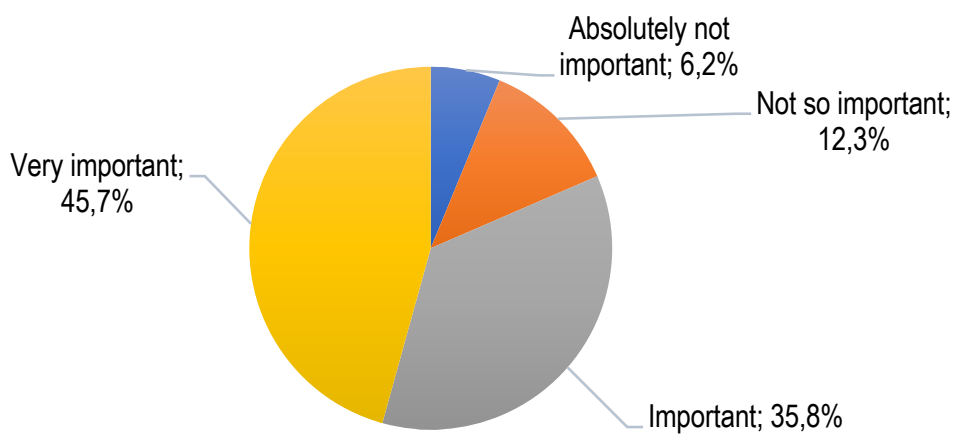

Figure 10. A common language used in company structures Sources: developed by the authors. 


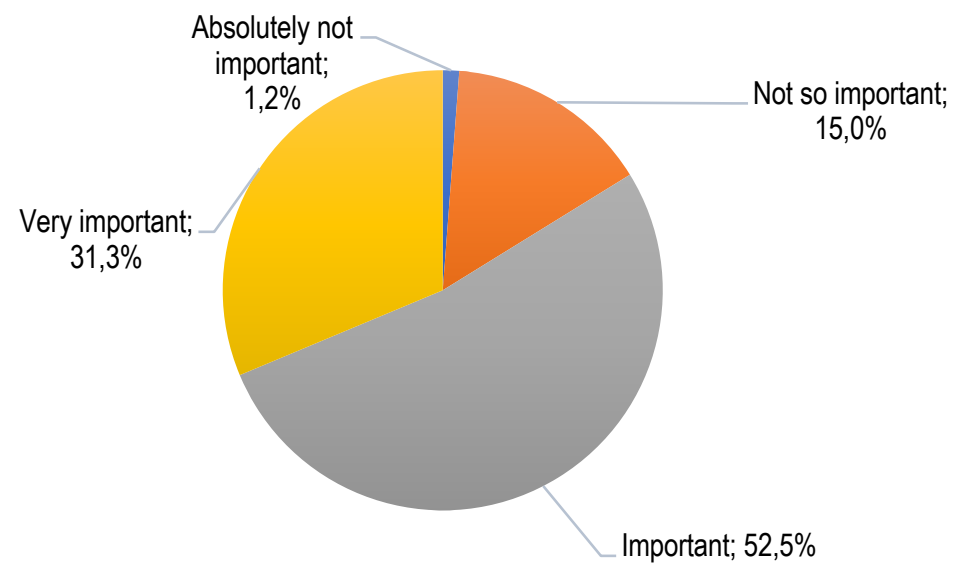

Figure 11. Incentive remuneration system based on the achieved goals of the company's global

Sources: developed by the authors.

\section{strategy}

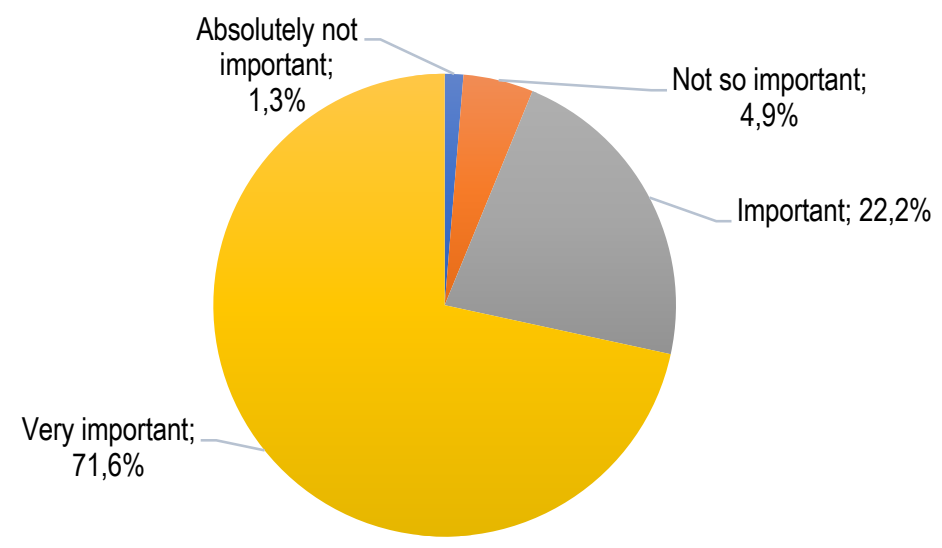

Figure 12. Building trust and commitment between employers and employees.

Sources: developed by the authors.

More than $70 \%$ chosen «very important». As it could be seen, there are no more choices «no important» than «important». From these points, it could be stated that the following activities support employees. Thus, the employees need the global strategy. Table 9 presents the answers question «What are the biggest benefits of global strategy?». Thus, most respondents voted for an increase in profits because of as much as $18 \%$. In the second place is brand recognition (17\%).

Sales increase and Better product and program quality with a result of $16 \%$ are in third place. A slightly larger decrease in votes could be seen in Increased customer performance - 14\%. Finally, respondents see the least benefit of global strategy in Increased competitive leverage and Cost reduction. Table 10 provides information regarding the injury: «global strategy in your company». The bottom scale shows three possible answers to the question «Does your employer give you the opportunity to expand your 
knowledge of global strategy in your company?», which were: I'm not sure, no, and yes. The findings showed that $52 \%$ of asking people answers «Yes», $15 \%$ people - «l'm not sure» and $13 \%-$ «No».

Table 9. What are the biggest benefits of a global strategy?

\begin{tabular}{cc}
\hline Answers & Votes \\
\hline Better product and program quality & 34 \\
Brand recognition & 37 \\
Cost reduction & 21 \\
Increased competitive leverage & 18 \\
Increased customer performance & 29 \\
Profit increase & 39 \\
Sales increase & 34 \\
All votes & 212 \\
\hline
\end{tabular}

Sources: developed by the authors.

Table 10. Does your employer give you the opportunity to expand your knowledge of global strategy in your company?

\begin{tabular}{cc}
\hline & Votes \\
\hline Answers & 15 \\
I'm not sure & 13 \\
No & 52 \\
\hline
\end{tabular}

Sources: developed by the authors.

In turn, more than $50 \%$ of the asking people are educated in the level of global strategy. It seems that companies give an input to develop global acknowledge between the workers. Unfortunately, it's unknown what kind of methods, media, or other programs was used to expand this education. In conclusion, it could be stated that awareness about a company's global strategy is important knowledge among employees.

Table 11. What is the main way to disseminate knowledge about the strategy, vision, mission, news or changes in your company?

\begin{tabular}{cc}
\hline Answers & Votes \\
\hline Social media (FB, Instagram) & 12 \\
Eecieved and sent orally by employees & 26 \\
From the immediate supervisor & 6 \\
Internal information system & 6 \\
Others (Company meetings) & 29 \\
Others (All internet sources) & 1 \\
\hline
\end{tabular}

Sources: developed by the authors.

In extending employees' knowledge of strategies, most people (36\% of responders) consider the internal information system (corporate messengers) as the best means of information exchange. According to employees, emails (31\%) also play an important role in company communication. $15 \%$ of respondents consider social media as one of the tools to provide information to employees about the company's strategy. The least people think the good solutions for transmitting information are those received and sent orally by employees and from the immediate supervisor (both $8 \%$ ). Some respondents think all internet sources (1\%) and company meetings (1\%) are good types of information transfer.

It stands to mention that most respondents found that the most effective way of communicating information about global strategy is the internal information system. Social media comes second. It's 
nothing unusual since nowadays, social media play a significant role in life. A huge part of the young generation earns money thanks to social media.

Table 12. What do you think is the most effective way of communicating information about the global strategy?

\begin{tabular}{cc}
\hline Answers & Quantity \\
\hline Social media (Fb, Instagram etc.) & 21 \\
Internal information system & 27 \\
Email messages & 14 \\
From the immediate supervisor & 11 \\
Received and sent orally by employees & 4 \\
All internet sources & 3 \\
\hline
\end{tabular}

Sources: developed by the authors.

Conclusions. This study evaluated that employees having less knowledge about global policies and plans of their corresponding organization remain unable to produce maximum business-related results due to which organization's overall performance is affected. At the same time, the employees who have sufficient knowledge about global strategies and plans of their corresponding organization could pay their full attention and utilize their energies to grow the business for their organizations. Besides, the study results highlighted that most of the business companies are dealing with sales and distribution. However, the portion of the mining industry and construction industry is considerably low. Most companies have clients outside the country. Therefore, moving towards the company's global strategy and employees of the company have reasonable awareness. Companies also have a major portion of international suppliers.

The study revealed that companies have the global strategy, as most employees highlighted that the company is working through the global strategy. However, few employees highlighted that they do not have the idea about global strategy. Most of the employees acknowledged that the company has the global strategy. Therefore, the employees have an awareness of the global strategy. Along with this, many employees also acknowledged that global strategy is most important for the company. Moreover, most of the employees showed interest in global strategy. According to the employees, they are willing that the company should have global strategy as a higher number of employees acknowledged that global strategy has many benefits. Thus, to achieve higher performance through global strategy benefits, a company must have well planned global strategy.

It is also evident from the results that awareness about the global strategy can promote the employees' motivational level. Therefore, employees want to adopt the global strategy. Employees also highlighted that global strategy is important for brand building, innovation, and expansion to the new market. According to the employees, the major benefits of the global strategy include increasing the product quality, increasing sales, brand recognition promotion, increasing the profit, increasing the customers, gaining competitive advantage, and reducing the cost. Companies are also providing opportunities to the employees to increase their knowledge about the global strategy. Knowledge management has key importance for the global strategy. Employees recommended that to promote the global strategy, the company must have a better internal information system and social media coverage. Therefore, the study results showed the employees have sufficient knowledge about the global strategy and have a significant level of awareness to promote global strategy.

Implications of the Study: The current study has several theoretical and practical implications. The current study is one of the unique studies that examined employees' awareness about the employees of large enterprises from Poland. This study contributed to the literature by examining the awareness level of employees about the global strategy. It is an important investigation that is not documented in previous 
studies. Notably, large enterprises from Poland were not considered by the previous studies. Therefore, this study significantly contributed to the body of knowledge.

Along with the theoretical implications, the current study also has practical implications. The results of this study are quite helpful for the practitioners to promote awareness among the employees concerning the global strategy. This study highlighted that to get higher benefits from global strategy, and employees should be aware of the global strategy. Therefore, management of the companies should promote the level of awareness among the employees about the global strategy to attain higher benefits.

Funding: This research received no external funding.

\section{References}

Addison, P. F., Stephenson, P. J., Bull, J. W., Carbone, G., Burgman, M., Burgass, M. J., ... \& Milner-Gulland, E. J. (2020) Bringing sustainability to life: A framework to guide biodiversity indicator development for business performance management. Business Strategy and the Environment, 29(8), 3303-3313. [Google Scholar] [CrossRef]

Al-Dmour, H. H., Asfour, F., Al-Dmour, R., \& Al-Dmour, A. (2020). The Effect of Marketing Knowledge Management on Bank Performance Through Fintech Innovations: A Survey Study of Jordanian Commercial Banks. Interdisciplinary Journal of Information, Knowledge, and Management, 15, 203-225. [Google Scholar] [CrossRef]

Altaf, M., Hameed, W., Nadeem, S., \& Shahzad, A. (2019). Successful entrepreneurial process as contributor towards business performance in banking: moderating role of passion for inventing. South Asian Journal of Management Sciences, 13(1), 13-40. [Google Scholar]

Bilan, S., Mishchuk, H., Samoliuk, N. \& Ostasz, G. (2019). Effectiveness of Social Dialogue in the System of Sustainable Economic Development Factors. Paper presented at the Proceedings of the 34th International Business Information Management Association Conference, IBIMA 2020: Vision 2025: Education Excellence and Management of Innovations through Sustainable Economic Competitive Advantage, 13303-13313.

Bilan, Y., Mishchuk, H., Samoliuk, N., \& Mishchuk, V. (2020). Gender discrimination and its links with compensations and benefits practices in enterprises. Entrepreneurial Business and Economics Review, 8(3), 189-203. [Google Scholar] [CrossRef]

Carpenter, M. A., Pollock, T. G., \& Leary, M. M. (2003). Testing a model of reasoned risk-taking: governance, the experience of principals and agents, and global strategy in high-technology IPO firms. Strategic management journal, 24(9), 803-820. [Google Scholar] [CrossRef]

Chan, C. M. H., Wong, J. E., Yeap, L. L. L., Wee, L. H., Jamil, N. A., \& Nantha, Y. S. (2019). Workplace bullying and psychological distress of employees across socioeconomic strata: a cross-sectional study. BMC public health, 19(4), 1-8. [Google Scholar] [CrossRef]

Chen, Y., Li, X., Wang, L., \& Wang, S. (2017). Is China different from other investors in global land acquisition? Some observations from existing deals in China's going global strategy. Land Use Policy, 60, 362-372. [Google Scholar] [CrossRef]

Chisholm, D., Moro, D., Bertram, M., Pretorius, C., Gmel, G., Shield, K., \& Rehm, J. (2018). Are the «best buys» for alcohol control still valid? An update on the comparative cost-effectiveness of alcohol control strategies at the global level. Journal of studies on alcohol and drugs, 79(4), 514-522. [Google Scholar] [CrossRef]

Dzwigol, H., Dzwigol-Barosz, M., Miskiewicz, R., \& Kwilinski, A. (2020). Manager Competency Assessment Model in the Conditions of Industry 4.0. Entrepreneurship and Sustainability Issues, 7(4), 2630-2644. [CrossRef]

Fitriyah, N. (2019). Multivariate analysis of strategic management and business development in service sector. Polish Journal of Management Studies, 19(1), 145-156. [CrossRef]

Girchenko, T., Panchenko, O. (2020). Research on the practical aspects of the providing efficiency of marketing communications' bank. Financial and credit activity-problems of theory and practice, 3. P. 13-22. [Google Scholar] [CrossRef]

Hafiz, M. T., \& Sary, F. P. (2020). Analysis of the influence of compensation and transformational leadership style on employee performance in PT. Finnet Indonesia. Paper presented at the Digital Economy for Customer Benefit and Business Fairness: Proceedings of the International Conference on Sustainable Collaboration in Business, Information and Innovation (SCBTII 2019), Bandung, Indonesia, October 9-10, 2019. Retrieved from [Link]

Hussain, H. I., Kot, S., Kamarudin, F., \& Wong, C. M. (2020). The Nexus of competition freedom and the efficiency of microfinance institutions. Journal of Competitiveness, 12(2), 67. [Google Scholar] [CrossRef]

Iqbal, J., \& Hameed, W. U. (2020). Open Innovation Challenges and Coopetition-Based Open-Innovation Empirical Evidence From Malaysia. In Innovative Management and Business Practices in Asia (pp. 144-166). IGI Global. [Google scholar] [CrossRef]

Karami, A., Dolatabadi, H. R., \& Rajaeepour, S. (2013). Analyzing the effectiveness of reward management system on employee performance through the mediating role of employee motivation case study: Isfahan Regional Electric Company. International Journal of Academic Research in Business and Social Sciences, 3(9), 327. [Google Scholar] 
Karim, M. R., Huda, K. N., \& Khan, R. S. (2012). Significance of training and post training evaluation for employee effectiveness An empirical study on Sainsbury's Supermarket Ltd, UK. International Journal of Business and Management, 7(18), 141. [Google Scholar]

Khuong, N. V., Liem, N. T., \& Minh, M. T. H. (2020). Earnings management and cash holdings: Evidence from energy firms in Vietnam. Journal of International Studies, 13(1). [Google Scholar] [CrossRef]

Kot, S., Haque, A. U., \& Baloch, A. (2020). Supply chain management in SMEs: Global perspective. Montenegrin Journal of Economics, 16(1), 87-104. [Google Scholar]

Kovacs, G. (2020). Combination of Lean value-oriented conception and facility layout design for even more significant efficiency improvement and cost reduction. International Journal of Production Research, 58(10), 2916-2936. [Google Scholar] [CrossRef]

Kuznetsova A., Kalynets K., Kozmuk N. (2018). Innovative management in global financial csr governance. Marketing and management of innovations, 2, P. 262-269. [CrossRef]

Kwilinski, A. (2018). Mechanism of formation of industrial enterprise development strategy in the information economy. Virtual Economics, 1(1), 7-25. [CrossRef]

Liem, V. T., \& Hien, N. N. (2020). The impact of manager's demographic characteristics on prospector strategy, use of management accounting systems and financial performance. Journal of International Studies, 13(4), 54-69. [Google Scholar] [CrossRef

Lorenzen, M., \& Mahnke, V. (2002). Global strategy and the acquisition of local knowledge: how MNCs enter regional knowledge clusters. Aalborg and Copenhagen: Danish Research Unit of Industrial Dynamics, DRUID Working Paper Series, 8. [Google Scholar]

Lukitowati, R., \& Ramli, K. (2020). Assessing the Information Security Awareness of Employees in PT ABC Against Internationa Organization for Standardization (ISO) 27001: 2013. Journal of Computational and Theoretical Nanoscience, 17(2), 1441-1446. [Google Scholar] [CrossRef]

Micík, M., \& Micudova, K. (2018). Employer brand building: Using social media and career websites to attract generation Y. Economics \& Sociology, 11(3), 171-189. [Google Scholar] [CrossRef]

Omar, S. R., Ab Karim, S., Isa, S. S., \& Omar, S. N. (2020). Enlivening the effect of tourists' knowledge and involvement on Malaysian heritage food (MHF) towards food tourism image in Malaysia. In Destination Management and Marketing: Breakthroughs in Research and Practice (pp. 268-290). IGI Global. [Google Scholar] [CrossRef]

Onyusheva, I. (2017). Analytical and managerial issues of human capital in conditions of global competitiveness: the case of Kazakhstan. Polish Journal of Management Studies, 16. [Google Scholar] [CrossRef]

Petru, N., Havlícek, K., \& Tomaškova, A. (2018). Comparison of marketing vitality of family and non-family companies doing business in Czech republic. Economics \& Sociology, 11(2), 138-156. [Google Scholar] [CrossRef]

Rotvold, G. (2008). How to create a security culture in your organization: A recent study reveals the importance of assessment incident response procedures, and social engineering testing in improving security awareness programs. Information Management Journal, 42(6), 32-38. [Google Scholar]

Sharrock, S., Hoft, R., \& Dias, B. F. D. S. (2018). An overview of recent progress in the implementation of the Global Strategy for Plant Conservation-a global perspective. Rodriguésia, 69(4), 1489-1511. [Google Scholar] [CrossRef]

Stverkova, H., Pohludka, M., Kurowska-Pysz, J., \& Szczepanska-Woszczyna, K. (2018). Cross-border enterprepreneurship in Euroregion Beskydy. Polish Journal of Management Studies, 18. [Google Scholar] [CrossRef]

Tahir, N., Yousafzai, I. K., Jan, S., \& Hashim, M. (2014). The impact of training and development on employees performance and productivity a case study of United Bank Limited Peshawar City, KPK, Pakistan. International Journal of Academic Research in Business and Social Sciences, 4(4), 86. [Google Scholar]

Trad, A., \& Kalpic, D. (2018). The Business Transformation and Enterprise Architecture Framework: The Financial Engineering Global Strategy Regaining Global Stability After the Financial Crisis (pp. 1-22): IGI Global. [CrossRef]

Widokarti, J. R., Kartini, D., Oesman, Y. M., \& Sari, D. (2019). An Analysis of the Relationship between Compensation and Employees' Working Motivation Controlling for Proactive Behavior in Indonesian Hotel Industry. Mediterranean Journal of Social Sciences, 10(3), 70. [Google Scholar]

Wisse, B., van Eijbergen, R., Rietzschel, E. F., \& Scheibe, S. (2018). Catering to the needs of an aging workforce: The role of employee age in the relationship between corporate social responsibility and employee satisfaction. Journal of Business Ethics, 147(4), 875-888. [Google Scholar]

Wolfmayr, K. (2020). High Speed Strategy Implementation in a Global, Dynamic Business Environment/submitted by Klaus Wolfmayr, BSc. Universität Linz. [Google Scholar]

Zhang, X., Kuchinke, L., Woud, M. L., Velten, J., \& Margraf, J. (2017). Survey method matters: Online/offline questionnaires and face-to-face or telephone interviews differ. Computers in Human Behavior, 71, 172-180. [Google Scholar] [CrossRef]

Маріуш Урбанський, Ph.D.,Ченстоховський політехнічний університет, Польща

Обізнаність працівників як складова глобальної конкурентної стратегії компанії

Ця стаття узагальнює аргументи та контраргументи в межах наукової дискусії з питання визначення імперативів формування глобальної конкурентної стратегії компанії. Розкрито сутність глобальної конкурентної стратегії. Визначено, що глобальна конкурентна стратегія компанії впливає на підвищення показників продуктивності праці її працівників. Теоретично обґрунтовано необхідність поінформованості працівників компанії з основними аспектами глобальної конкурентної стратегії 
компанії з метою досягнення запланованих показників ефективності її впровадження. Основною метою статті є дослідження рівня обізнаності працівників щодо глобальної стратегії компанії на прикладі великих підприємств Польщі. Детерміновану вибірку даних сформовано на основі результатів опитування 82 працівників великих підприємств Польщі. Методичним інструментарієм дослідження стали методи поперечних зрізів, дескриптивної статистики. Результати емпіричного аналізу засвідчили, що зростання рівня обізнаності працівників про діяльність компанії сприяє підвищенню їх мотивації. За результатами дослідження встановлено, що працівники вважають глобальну стратегію компанії невід'ємною складовою при створенні бренду та виходу на нові ринки. Головною перевагою глобальної стратегії компанії є підвищення якості її продукції, зростання рівня продажів, просування бренду, збільшення прибутку та кількості споживачів, підвищення конкурентних переваг та зниження собівартості. Враховуючи отримані результати, автором наголошено на необхідності формування ефективної глобальної стратегії для підвищення результативності бізнес-діяльності. Результати дослідження мають практичне значення і можуть бути прийняті до впровадження з метою просування великих підприємств у Польщі.

Ключові слова: глобальна стратегія, обізнаність працівників, великі підприємства, управління знаннями. 